\title{
Assessment of Properties of Concrete with Partial Replacement of Various Constituents
}

\author{
Achal Agrawal \\ Department of Civil Engineering \\ Sanghvi Institute of Management and Science, Indore (MP) \\ Lovish Pamecha \\ Asst. Prof. of Department of Civil Engineering \\ Sanghvi Institute of Management and Science, Indore (MP)
}

\begin{abstract}
Preservation of environment and conservation of natural resources is the essence of any development. Also the present $R$ and $D$ continuously are dealing with technological and industrial development on waste management. In order to address environmental effects associated with cement manufacturing, it is crucial to advance alternative binders to compose concrete. Consequently extensive delving is continuing, on substitution of cement by differing waste materials and industrial offshoot. As partial replacement of cement and/or aggregate attempts on fly ash, demolished concrete, waste glass, rice husk etc. have already been accomplished in concrete industries. If few waste materials found convenient and economical for concrete manufacturing, a major gain will be achieved in disposal of waste management and depression in construction cost. The work audits the feasibility of fly ash, glass powder and demolished concrete as partial substitute of cement and natural coarse aggregate respectively. For this intent, procedure is partitioned into two stages. The initial stage proceeds with replacing $25 \%$ cement content by variant proportions of fly ash (FA) and glass powder (GP). Further tested for compressive and flexural strength, at 7 days, 14 days \& 28 days and correlated with conventional concrete. The adequate results were attained with the combination of cement $75 \%$ and fly ash $25 \%$ in ratio, w.r.t properties tested. In second stage, same optimum ratio of cement and fly ash is added with partly replaced natural coarse aggregate (NCA) with recycled concrete aggregate (RCA) in concrete. For test intent, recycled aggregates were accessed from crushed concrete cubes of grade M25 in laboratory. Variant composition of natural coarse aggregate and recycled aggregate adopted and test samples from this matrix were prepared for the same test as mentioned above. Observations reveal, combination of $90 \%$ NCA and 10\% RCA in ratio, leads to adequate results.
\end{abstract}

Keywords:- Compressive Strength, Flexural Strength, Fly Ash (FA), Glass Powder (GP), Natural Coarse Aggregates (NCA), Recycled Concrete Aggregates (RCA)

\section{INTRODUCTION}

During recent years the consciousness regarding environmental atrocity has increased as a result the interest of construction community in using waste or recycled materials in concrete has also aggravated. If we see around us, we can see so many materials we consider waste which rather must be seen as opportunities. The waste glass pieces from the shops are disposed off as waste material but glass being an inert substance can be recycled without any chemical reaction. The fly ash is produced in abundance in the thermal power plants as abate product which is not easy to be disposed off and is dangerous to the environment. Recycled concrete aggregate is produced by crushing concrete to reclaim the aggregate. Recycled aggregate can be used for many purposes. The primary market is road base for information on recycling asphalt pavement into new asphalt pavement. Aggregate resulting from the processing of inorganic material previously used in construction and principally comprising crushed concrete washed and graded for use as an aggregate in the production of further concrete. The project includes utilization of cement which may be partially replaced by fly ash and Glass Powder. In the 1st phase of work in 7 batches of different proportions of binders have been readied and cubes and beams have been casted. Outcomes acquired were analyzed and proportions that provide optimum values have been taken for the next stage. In second stage of work, Natural Aggregates have been partially replaced by Recycled Concrete Aggregates. Furthermore 5 batches have been prepared and results will be investigated.

\section{EXPERIMENTAL WORK}

\subsection{Material Used:}

The materials used for this work is cement (C), sand (S), fly ash (FA), glass powder (GP), natural coarse aggregates (NCA) \& recycled concrete aggregates (RCA). Potable water was used for getting concrete mix. FA was collected from thermal plant near Khandwa, MP. Broken glass pieces were collected from local source and 
then were crushed to get powder. Sieve analysis was conducted on GP to obtain particle size equivalent to cement. Demolished concrete was collected from laboratory and then broken into small pieces to get $20 \mathrm{~mm}$ to $25 \mathrm{~mm}$ size aggregates (RCA). Some of the physical properties were obtained in the laboratory of the materials are given in table 1 .

Table 1: Properties of material

\begin{tabular}{|c|c|}
\hline Properties & Value \\
\hline \multicolumn{2}{|c|}{ Cement } \\
\hline Initial Setting Time & $35 \mathrm{Min}$ \\
\hline Final Setting Time & $585 \mathrm{Min}$ \\
\hline \multicolumn{2}{|c|}{ Sand } \\
\hline \multicolumn{2}{|c|}{ Silt Content } \\
\hline \multicolumn{2}{|c|}{ Aggregates } \\
\hline Impact value & 15.15 \\
\hline Flakiness Index & 37.83 \\
\hline Elongation Index & 30.86 \\
\hline
\end{tabular}

\subsection{Problem Formulation}

Stage-1 of work:

In this stage of work cement is partially replaced by FA \& GP in different percentages as shown in the table below. 7 batches are prepared in different proportions including conventional concrete mix (Cement as binder,Sand as fine aggregates \& Natural Coarse Aggregates). Cubes and beams are casted for determining compressive and flexural strengths respectively at 7, 14 and 28 days. (refer Table 2)

Table 2: Formulation of work (Stage-1)

\begin{tabular}{|c|c|c|c|c|c|}
\hline $\begin{array}{l}\text { Batch } \\
\text { Mix }\end{array}$ & Cement (\%) & FA (\%) & GP (\%) & $\begin{array}{c}\text { Sand } \\
\text { (\%) }\end{array}$ & $\begin{array}{l}\text { Natural Coarse } \\
\text { Aggregates (\%) }\end{array}$ \\
\hline 1 & 100 & -- & -- & 100 & 100 \\
\hline 2 & 75 & 25 & 00 & 100 & 100 \\
\hline 3 & 75 & 20 & 05 & 100 & 100 \\
\hline 4 & 75 & 15 & 10 & 100 & 100 \\
\hline 5 & 75 & 10 & 15 & 100 & 100 \\
\hline 6 & 75 & 05 & 20 & 100 & 100 \\
\hline 7 & 75 & 00 & 25 & 100 & 100 \\
\hline
\end{tabular}

Stage-2 of work:

Results obtained from stage 1 are considered for stage 2. Proportions of the batch giving optimum values of Compressive Strength and Flexural Strength are taken for this stage of work. In the table below x, y \& $\mathrm{z}$ are showing $\%$ of cement, FA \& GP in stage 1 which is giving optimum results. In this stage NCA is partially replaced by RCA in different proportion as shown here. As stage-1, cubes and beams are casted for different proportions to determine compressive and flexural strengths respectively at 7, 14 and 28 days. 


\begin{tabular}{|c|c|c|c|c|c|c|}
\hline Batch Mix & $\begin{array}{c}\text { Cement } \\
\text { (\%) }\end{array}$ & $\begin{array}{l}\text { Fly } \\
\text { Ash } \\
(\%)\end{array}$ & $\begin{array}{c}\text { Glass } \\
\text { Powder } \\
\text { (\%) }\end{array}$ & $\begin{array}{l}\text { Sand } \\
(\%)\end{array}$ & $\begin{array}{c}\text { Natural } \\
\text { Coarse } \\
\text { Aggregate } \\
(\%)\end{array}$ & $\begin{array}{c}\text { Recycle } \\
\text { Concrete } \\
\text { Aggregate (\%) }\end{array}$ \\
\hline Batch Mix -1 & 100 & 0 & 0 & 100 & 100 & 0 \\
\hline Batch Mix -2 & 75 & 25 & 0 & 100 & 100 & 0 \\
\hline Batch Mix -3 & 75 & 25 & 0 & 100 & 90 & 10 \\
\hline Batch Mix -4 & 75 & 25 & 0 & 100 & 80 & 20 \\
\hline Batch Mix -5 & 75 & 25 & 0 & 100 & 70 & 30 \\
\hline Batch Mix -6 & 75 & 25 & 0 & 100 & 60 & 40 \\
\hline
\end{tabular}

Compressive Strength

III. TEST CONDUCTED \& RESULTS

Nine cubes are casted in each batch mix for determining compressive strength. Tests are performed at the age of 7 days, 14 days and 28 days of the specimens. Specimens are placed in the test machine as per IS: 516-1959 clause no 5.5.1 page no 11, also loading is applied on the specimen as per the same IS code.

Calculation are made by dividing the maximum applied load by the cross sectional area of the specimen. As there are three specimens for each batch mix, the average of the three values is taken.

Table 4: Compressive Strength Result (Stage 1)

\begin{tabular}{|c|c|c|c|c|}
\hline \multirow{2}{*}{ S.N. } & \multirow{2}{*}{ Combination } & \multicolumn{3}{|c|}{ Compressive Strength $\left(\mathbf{N} / \mathbf{m m}^{2}\right.$ ) at } \\
\cline { 3 - 5 } & 7 Days & $\mathbf{1 4}$ Days & 28 days \\
\hline Mix-01 & $\mathrm{C}+\mathrm{S}+\mathrm{NCA}$ & 18.17 & 20.63 & 24.13 \\
\hline Mix-02 & $\begin{array}{c}75 \% \mathrm{C}+\mathrm{S}+\mathrm{NCA}+ \\
25 \% \mathrm{FA}+0 \% \mathrm{GP}\end{array}$ & 23.20 & 26.40 & 30.61 \\
\hline Mix-03 & $\begin{array}{c}75 \% \mathrm{C}+\mathrm{S}+\mathrm{NCA}+ \\
20 \% \mathrm{FA}+5 \% \mathrm{GP}\end{array}$ & 21.74 & 24.72 & 28.67 \\
\hline Mix-04 & $\begin{array}{c}75 \% \mathrm{C}+\mathrm{S}+\mathrm{NCA}+ \\
15 \% \mathrm{FA}+10 \% \mathrm{GP}\end{array}$ & 21.08 & 24.03 & 27.36 \\
\hline Mix-05 & $\begin{array}{c}75 \% \mathrm{C}+\mathrm{S}+\mathrm{NCA}+ \\
10 \% \mathrm{FA}+15 \% \mathrm{GP}\end{array}$ & 18.91 & 21.75 & 25.16 \\
\hline Mix-06 & $\begin{array}{c}75 \% \mathrm{C}+\mathrm{S}+\mathrm{NCA}+ \\
5 \% \mathrm{FA}+20 \% \mathrm{GP}\end{array}$ & 17.23 & 19.87 & 22.86 \\
\hline Mix-07 & $\begin{array}{c}75 \% \mathrm{C}+\mathrm{S}+\mathrm{NCA}+ \\
0 \% \mathrm{FA}+25 \% \mathrm{GP}\end{array}$ & 15.36 & 17.71 & 20.32 \\
\hline
\end{tabular}

Table 5: Compressive Strength Result (Stage 2)

\begin{tabular}{|c|c|c|c|c|}
\hline \multirow{2}{*}{ S.N. } & \multirow{2}{*}{ Combination } & \multicolumn{3}{|c|}{ Compressive Strength $\left(\mathbf{N} / \mathbf{m m}^{2}\right.$ ) at } \\
\cline { 3 - 5 } & Mix-01 & 7 Days & 14 Days & 28 days \\
\hline Mix-02 & $\begin{array}{c}75 \% \mathrm{C}+\mathrm{S}+25 \% \mathrm{~S}+\mathrm{NCA}+ \\
0 \% \mathrm{GP}+100 \% \mathrm{NCA}\end{array}$ & 23.20 & 26.40 & 24.13 \\
\hline Mix-03 & $\begin{array}{c}75 \% \mathrm{C}+\mathrm{S}+25 \% \mathrm{FA}+ \\
0 \% \mathrm{GP}+90 \% \mathrm{NCA}+10 \\
\% \mathrm{RCA}\end{array}$ & 23.49 & 27.36 & 31.02 \\
\hline Mix-04 & $\begin{array}{c}75 \% \mathrm{C}+\mathrm{S}+25 \% \mathrm{FA}+ \\
0 \% \mathrm{GP}+80 \% \mathrm{NCA}+20 \\
\% \mathrm{RCA}\end{array}$ & 20.58 & 24.51 & 27.36 \\
\hline
\end{tabular}




\begin{tabular}{|c|c|c|c|c|}
\hline Mix-05 & $\begin{array}{c}75 \% \mathrm{C}+\mathrm{S}+25 \% \mathrm{FA}+ \\
0 \% \mathrm{GP}+70 \% \mathrm{NCA}+30 \\
\% \mathrm{RCA}\end{array}$ & 19.91 & 23.02 & 26.52 \\
\hline Mix-06 & $\begin{array}{c}75 \% \mathrm{C}+\mathrm{S}+25 \% \mathrm{FA}+ \\
0 \% \mathrm{GP}+60 \% \mathrm{NCA}+40 \\
\% \mathrm{RCA}\end{array}$ & 19.68 & 22.74 & 26.24 \\
\hline
\end{tabular}

Flexural Strength

Beams of size $10 \mathrm{~cm} \times 10 \mathrm{~cm} \times 50 \mathrm{~cm}$ are casted for determining flexural strength. Test on beams are performed at the age of 7 days, 14 days \& 28 days of the specimen. Placement of specimen in machine is done as per IS: 5161959 in the clause no 8.3.1 page no 17. Load is applied at increasing rate of $1.8 \mathrm{KN} / \mathrm{min}$. Load is applied until specimen fails and load at which specimen fails is recorded. As specified in the IS code flexural strength is calculated and tabulated below:-

\begin{tabular}{|c|c|c|c|c|}
\hline \multirow{2}{*}{ S.N. } & \multirow{2}{*}{ Combination } & \multicolumn{3}{|c|}{ Flexural Strength (N/mm $\mathbf{2}^{2}$ at } \\
\cline { 3 - 5 } & & $\mathbf{7}$ Days & $\mathbf{1 4}$ Days & $\mathbf{2 8}$ days \\
\hline Mix-01 & C+S+NCA & 3.88 & 4.45 & 5.14 \\
\hline Mix-02 & $\begin{array}{c}75 \% \mathrm{C}+\mathrm{S}+\mathrm{NCA}+ \\
25 \% \mathrm{FA}+0 \% \mathrm{GP}\end{array}$ & 4.85 & 5.58 & 6.46 \\
\hline Mix-03 & $\begin{array}{c}75 \% \mathrm{C}+\mathrm{S}+\mathrm{NCA}+ \\
20 \% \mathrm{FA}+5 \% \mathrm{GP}\end{array}$ & 4.53 & 5.34 & 6.02 \\
\hline Mix-04 & $\begin{array}{c}75 \% \mathrm{C}+\mathrm{S}+\mathrm{NCA}+ \\
15 \% \mathrm{FA}+10 \% \mathrm{GP}\end{array}$ & 4.46 & 5.19 & 5.98 \\
\hline Mix-05 & $\begin{array}{c}75 \% \mathrm{C}+\mathrm{S}+\mathrm{NCA}+ \\
10 \% \mathrm{FA}+15 \% \mathrm{GP}\end{array}$ & 4.21 & 4.89 & 5.57 \\
\hline Mix-06 & $\begin{array}{c}75 \% \mathrm{C}+\mathrm{S}+\mathrm{NCA}+ \\
5 \% \mathrm{FA}+20 \% \mathrm{GP}\end{array}$ & 3.88 & 4.41 & 5.13 \\
\hline Mix-07 & $\begin{array}{c}75 \% \mathrm{C}+\mathrm{S}+\mathrm{NCA}+ \\
0 \% \mathrm{FA}+25 \% \mathrm{GP}\end{array}$ & 3.62 & 4.23 & 4.75 \\
\hline
\end{tabular}

Table 7: Flexural Strength Result (Stage 2)

\begin{tabular}{|c|c|c|c|c|}
\hline \multirow{2}{*}{ S.N. } & \multirow{2}{*}{ Combination } & \multicolumn{3}{|c|}{ Flexural Strength $\left(\mathrm{N} / \mathrm{mm}^{2}\right)$ at } \\
\hline & & 7 Days & 14 Days & 28 days \\
\hline Mix-01 & $\mathrm{C}+\mathrm{S}+\mathrm{NCA}$ & 3.88 & 4.45 & 5.14 \\
\hline Mix-02 & $\begin{array}{l}75 \% \mathrm{C}+\mathrm{S}+25 \% \mathrm{FA}+ \\
0 \% \mathrm{GP}+100 \% \mathrm{NCA}\end{array}$ & 4.85 & 5.58 & 6.43 \\
\hline Mix-03 & $\begin{array}{c}75 \% \mathrm{C}+\mathrm{S}+25 \% \mathrm{FA}+ \\
0 \% \mathrm{GP}+90 \% \mathrm{NCA}+10 \\
\% \mathrm{RCA} \\
\end{array}$ & 5.17 & 6.03 & 6.93 \\
\hline Mix-04 & $\begin{array}{c}75 \% \mathrm{C}+\mathrm{S}+25 \% \mathrm{FA}+ \\
0 \% \mathrm{GP}+80 \% \mathrm{NCA}+20 \\
\% \mathrm{RCA} \\
\end{array}$ & 4.22 & 4.92 & 5.65 \\
\hline Mix-05 & $\begin{array}{c}75 \% \mathrm{C}+\mathrm{S}+25 \% \mathrm{FA}+ \\
0 \% \mathrm{GP}+70 \% \mathrm{NCA}+30 \\
\% \mathrm{RCA}\end{array}$ & 4.18 & 4.83 & 5.57 \\
\hline Mix-06 & $\begin{array}{c}75 \% \mathrm{C}+\mathrm{S}+25 \% \mathrm{FA}+ \\
0 \% \mathrm{GP}+60 \% \mathrm{NCA}+40 \\
\% \mathrm{RCA}\end{array}$ & 4.12 & 4.74 & 5.32 \\
\hline
\end{tabular}

IV. DISCUSSION 
Compressive Strength:

Stage 1: Partial replacement of cement by FA \& GP

Graph 1 shows compressive strength for stage 1 at 7, $14 \& 28$ days curing period. It shows, compressive strength of Mix-02 when $25 \%$ cement is replaced by FA, a maximum value is achieved at all the three ages of concrete i.e. for $7,14 \& 28$ days. An increment of about $27 \%$ was found when compared with conventional concrete. On further replacement of cement by increasing percentage of GP and decreasing FA, a decreased strength was observed.

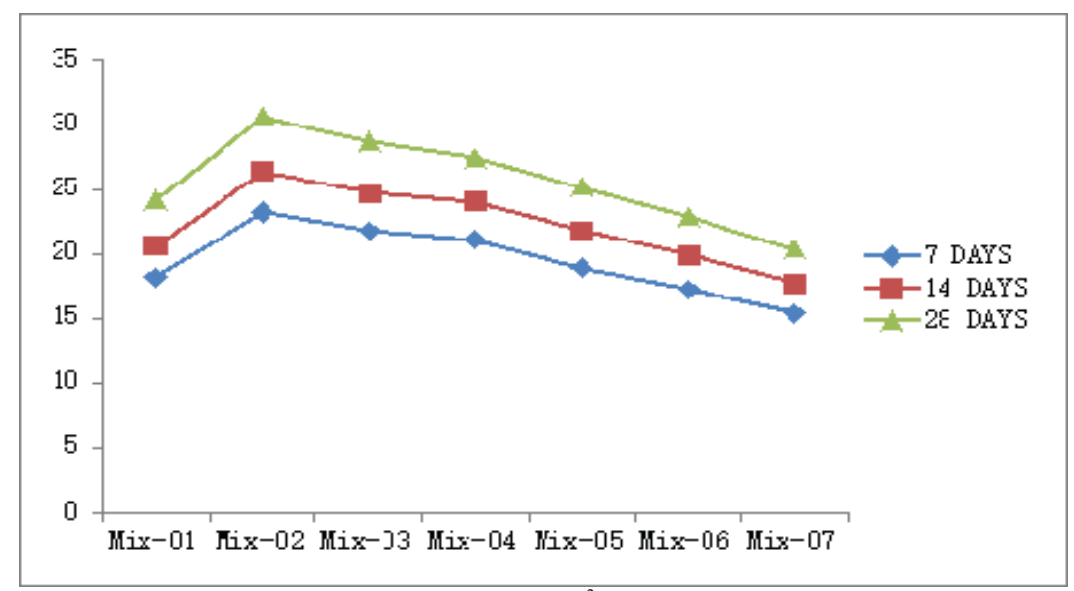

Graph 1: Compressive Strength in N/mm² at different age (Days) (Stage-1)

Stage 2: Partial replacement of NCA by RCA

Here, graph 2 is showing compressive strength for stage 2 at same $7,14 \& 28$ days of curing. When analyzed, strength of Mix-03 when 10\% NCA was replaced by RCA an approximately $29 \%$ of strength increased when compared with conventional mix, which is more $(2 \%)$ than optimum results of stage 1 . Also, on further increment of RCA, strength decrement was observed.

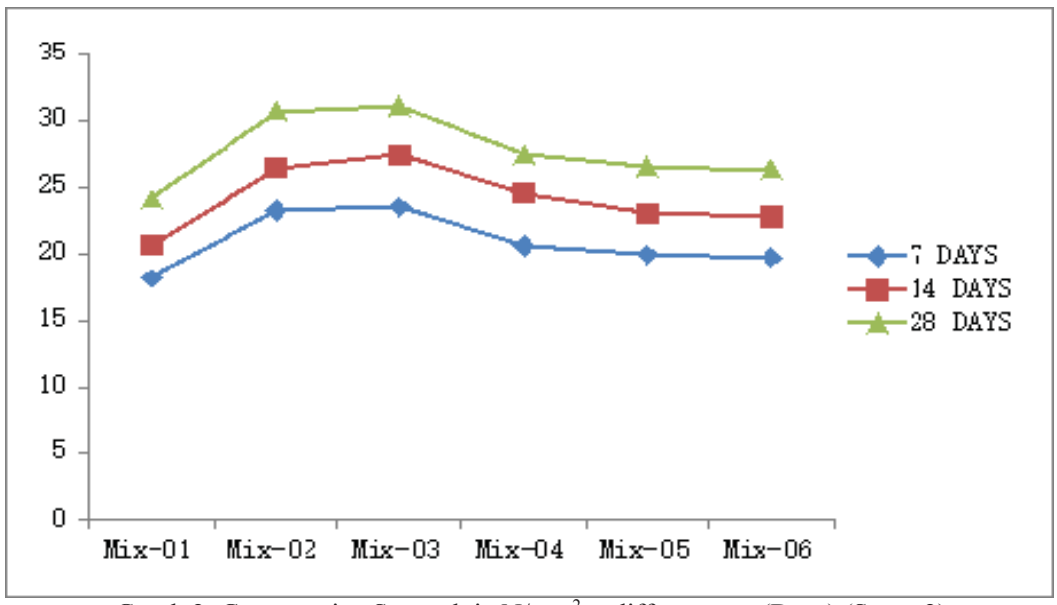

Graph 2: Compressive Strength in N/mm ${ }^{2}$ at different age (Days) (Stage-2)

Flexural Strength:

Stage 1: Partial replacement of cement by FA \& GP

In graph 3 flexural strength is shown for stage 1 at all three curing ages i.e. $7,14 \& 28$ days. In stage 1 when cement is $25 \%$ replaced by FA, a maximum flexural strength was achieved for mix- 02 . The increment that was observed was $25 \%$ as compared to conventional concrete mix. For flexural too, on increasing percentage of GP by decreasing FA, a decreased strength was observed. 


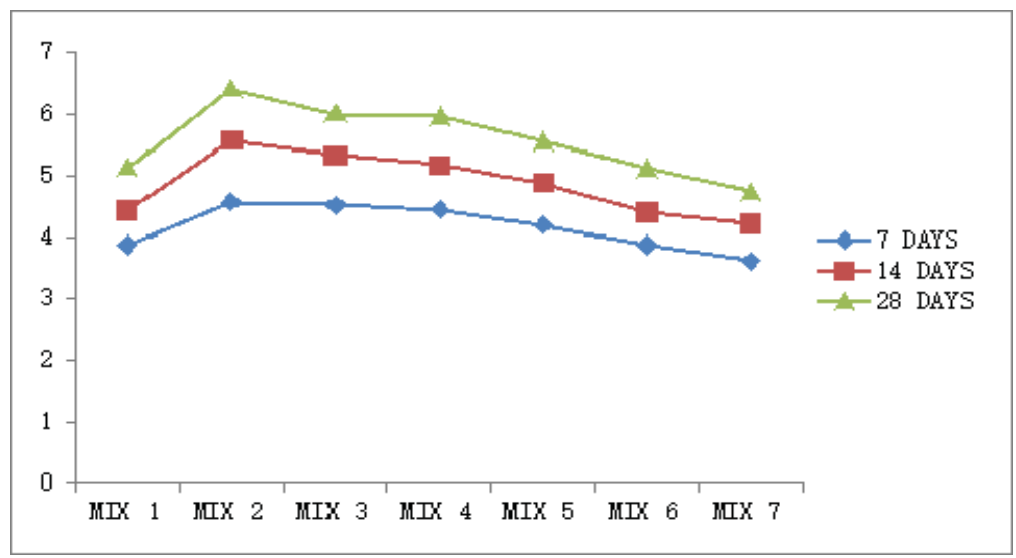

Graph 3: Flexural Strength in $\mathrm{N} / \mathrm{mm}^{2}$ at different age (Days) (Stage-1)

For stage 2 flexural strength, graph 4 is plotted which shows, there is an improved flexural strength is obtained. For mix-03 when $10 \%$ NCA was replaced by RCA, optimum strength was achieved. It was even more than maximum strength of stage 1. On further replacement of NCA by RCA decreased strength significantly.

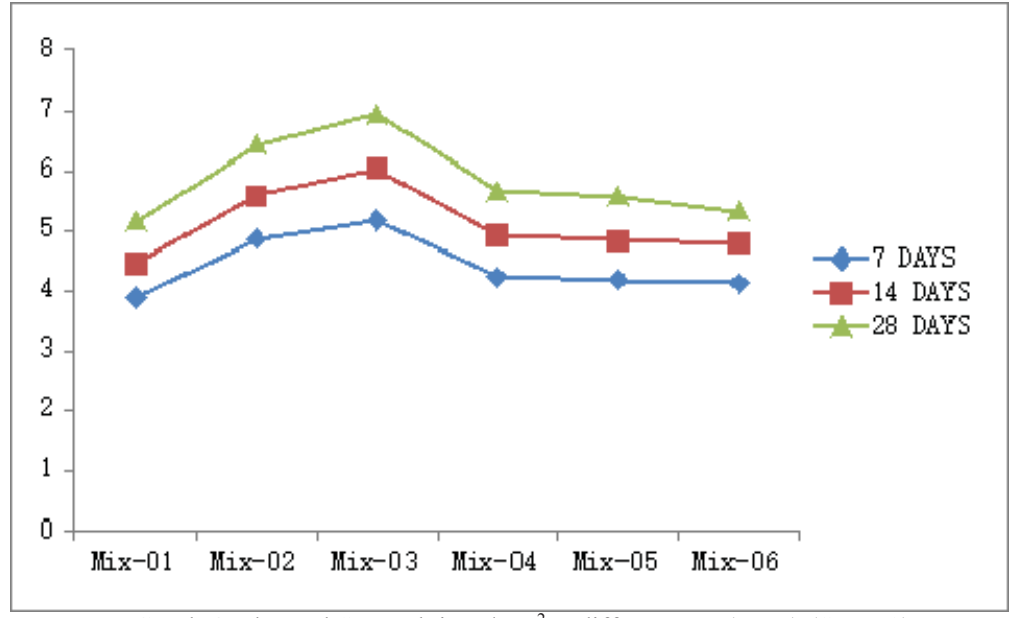

Graph 4: Flexural Strength in N/mm² at different age (Days) (Stage-2)

\section{CONCLUSION}

Based on the discussion and from graph $5 \&$ graph 6 , this research work can be concluded as:

$>$ The replacement of cement at an optimum percentage by FA (25\%), improved compressive and flexural strengths as compared to conventional concrete in stage-1.

$>$ In stage-1, on decreasing percentage replacement of FA $(25 \%$ to $0 \%)$ by increasing percentage replacement of GP $(0 \%$ to $25 \%)$, a decreased strength is determined, i.e. When GP is used as a replacement material, the strength of concrete gets reduced.

$>$ When mix proportion giving optimum strengths in stage- 1 is considered for stage-2, $10 \%$ NCA replacement by RCA gives a higher strength values for both compressive and flexural.

$>$ On increasing percentage replacement of RCA by replacing NCA, a continuous decrease in strength is investigated. It shown, only $10 \%$ replacement of NCA by RCA gives increased strength properties.

$>$ A maximum compressive and flexural strength is noted when $25 \%$ cement is replaced by FA \& $10 \%$ NCA are replaced by RCA for all 7 days, 14 days and 28 days curing period.

$>$ The increase in flexural strength is more when compared with compressive strength with replacement of conventional materials.

$>$ It was also observed that up to $10 \%$ and $15 \%$ replacement of cement by FA and GP respectively, investigated strengths were more than strengths of conventional concrete, hence depending upon availability of FA and GP, up to $10 \%$ FA and $15 \%$ GP can be used in place of cement without compromising strength. 

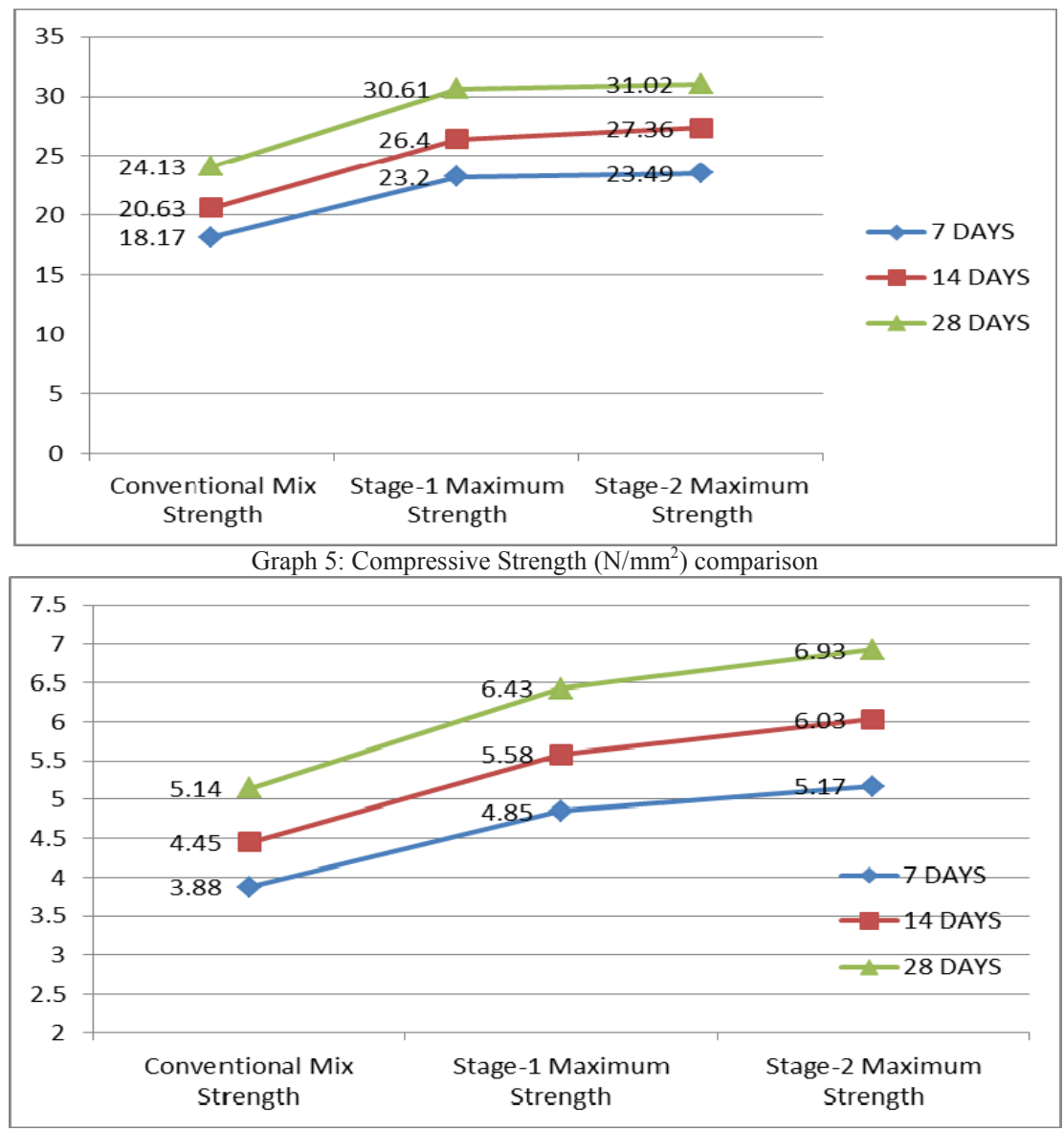

Graph 6: Flexural Strength (N/mm2) comparison

It can be concluded from this research work that FA can be used as a partial replacement of cement and RCA can be used as a partial replacement of NCA upto an optimum values. GP is not that useful as far as replacement of cement is concerned. A more detailed study can be carried out to discuss use of concrete having such materials in future.

\section{REFRENCES}

[1] M. R. Karim, M. F. M. Zain, M. Jamil, F. C. Lai and M. N. Islam, Strength development of mortar and concrete containing fly ash, International Journal of the Physical Sciences Vol. 6(17), pp. 4137-4153, 2 September, 2011

[2] D. N. Parekh and Dr. C. D. Modhera, Characterization of recycled aggregate concrete, International Journal of Advanced Engineering Technology E-ISSN 0976-3945 IJAET/Vol.II/ Issue IV/October-December, 2011/321-330

[3 ]R. NAGALAKSHMI,Experimental study on strength characteristics onM25 concrete with partial replacement of cementwith fly ash and coarse aggregate with coconutshell, International Journal of Scientific \& Engineering Research, Volume 4, Issue 1, January-2013,ISSN 2229-5518

[4] Dr. G.Vijayakumar, Ms H. Vishaliny, Dr. D. Govindarajulu,Studies on Glass Powder as Partial Replacement of Cement inConcrete Production, International Journal of Emerging Technology and Advanced Engineering, Volume 3, Issue 2, February 2013

[5] C.Marthong, T.P.Agrawal, Effect of Fly Ash Additive on Concrete Properties, International Journal of Engineering Research and Applications Vol. 2, Issue4, July-August 2012, pp.1986-1991

[6] Chandana Sukesh, Katakam Bala Krishna, P.Sri Lakshmi Sai Teja, S.Kanakambara Rao, Partial Replacement of Sand with Quarry Dust in Concrete, International Journal of Innovative Technology and Exploring Engineering (IJITEE) ISSN: 2278-3075, Volume-2, Issue-6, May 2013

[7] T. Phani Madhavi, V.Sampathkumar, P.Gunasekaran,Partial replacement of cement and fine aggregate byusing fly ash and glass aggregate,Conference Issue, Nov-2013

[8] B.Damodhara Reddy, S.Aruna Jyothy, Fawaz Shaik,Experimental analysis of the use of coconut shell as coarse aggregate, IOSR Journal of Mechanical and Civil Engineering (IOSR-JMCE) e-ISSN: 2278-1684,p-ISSN: 2320-334X, Volume 10, Issue 6 (Jan. 2014), PP 06-13

[9] Umapathy U 1, Mala C2, Siva K, Assessment of Concrete Strength Using PartialReplacement of Coarse Aggregate for waste Tiles and Cement for Rice Husk Ash in Concrete, Umapathy U et al Int. Journal of Engineering Research and Applications ISSN : 2248-9622, Vol. 4, Issue 5( Version 1), May 2014, pp.72-76 
[10] P.Padma Rao, A.Pradhan Kumar, B.Bhaskar Singh,A study on use of rice husk ash in concrete, IJEAR Vol. 4, Issue Spl-2, Jan June 2014

[11] M.N.N.Khana, M. Jamil, M.R. Karimc and M.F.M. Zain, Strength and Durability of Mortar and ConcreteContaining Rice Husk AshWorld Applied Sciences Journal 32 (5): 752-765, 2014

[12] Mangesh B. Mhatre, Dr. H. S. Chore, Prof. P. A. Dode,Studies on Utilization of Fly Ash and Rice Husk Ash in Concrete International Journal of Engineering and Technical Research (IJETR) ISSN: 2321-0869, Volume-2, Issue-11, November 2014

[13] Vivian W.Y. Tam, Kang Wang and C.M. Tam, Ways to facilitate the use of recycled aggregate concrete, Proceedings of the Institution of Civil EngineersWaste and Resource Management, 16August 2007 Issue WR3 Pages 125-129

[14] Tomas U. Ganiron Jr,Use of Recycled Glass Bottles as Fine Aggregates in Concrete Mixture, International Journal of Advanced Science and Technology, Vol.61, (2013), pp.17-28

[15] S R Yadav and S R Pathak, Use of recycled concrete aggregate in making concrete- An overview, $34^{\text {th }}$ Conference on Our World in Concrete \& Structures: 16 - 18 August 2009, Singapore

[16] Akinkurolere Olufunke Olanike, Experimental Study On Some Hardened Properties Of Air Entrained Recycled Aggregate Concrete, International Journal of Scientific \& Technology Research Volume 2, Issue 8, August 2013, ISSN 2277-8616

[17] A.N.Dabhade, Dr.S.R.Choudhari and Dr.A.R.Gajbhiye, Performance Evaluation of Recycled Aggregates Used in Concrete, International Journal of Engineering Research and Applications (IJERA), ISSN:2248-9622 vol.2, Issue4, July-August 2012, pp 13871391

[18] Hubert Chang, Ryan Morgan, Umed Aziz, Simon Herfellner \& Kenneth Ho, Performance and Implementation of Low-Quality Recycled Concrete Aggregate, The Journal of Sustainable Development, Vol. 10, Issue 1 (2013), Pp. $72-84$

[19] Prof. Chetna M.Vyas \& Prof. Jayeshkumar Pitroda,Fly Ash and Recycled Coarse Aggregate in Concrete: New Era for Construction Industries - A Literature Review, International Journal of Engineering Trends and Technology (IJETT) - Volume4Issue5- May 2013

[20] T.Manikandan, M.Mohan \& Y.M.Siddaharamaiah,Strength Study on Replacement of Coarse Aggregate by Reused Aggregate on Concrete, IJISET International Journal of Innovative Science, Engineering \& Technology, Vol. 2 Issue 4, April 2015, ISSN 2348 - 7968

[21] Jianzhuang Xiao \& Long Li, Review on Recycled Aggregate Concrete in the Past 15 Years in China

[22] G. Murali, C.M. Vivek Vardhan, Gabriela Rajan, G.J. Janani, N. Shifu Jajan and R. Ramya Sri, Experimental Study On Recycled Aggregate Concrete,International Journal of Engineering Research and Applications (IJERA), ISSN:2248-9622, Vol. 2, Issue 2, Mar-Apr 2012 , pp. $407-410$

[23] B.V.Bahoria, Dr.D.K.Parbat, Dr.P.B.Naganaik \& Dr.U.P.Waghe, Comprehensive literature review on use of waste product in concrete, International journal of Application or innovation in engineering of management,volume 2, issue 4, April 2013,ISSN $2319-4847$.

[24] Ansu John and Elson John, Study on the partial replacement of fine aggregate using induction furnace slag,American journal of engineering research(AJER),e-ISSN : 2320-0847,p-ISSN :2320-0936,Volume-4 pp-01-05

[25] M.R.Karim, M.F.Zain, M.Jamil, F.C.Lai, M.N.Islam, Strength of Mortar and Concrete as influenced by Rise Husk Ash,World Applied Sciences Journal 19 (10): 1501-1513,2012 ISSN 1818-4952. 